\title{
The Department of Agriculture Library and Its Services'
}

Mr. Shaw is librarian, U. S. Department of Agriculture.

Although the Department of Agri1 culture Library is more than 100 years old, its present scope and responsibilities date from the act which established the department, on May 15, 1862. This act states, "There shall be at the seat of Government a Department of Agriculture, the general design and duties of which shall be to acquire and to diffuse among the people of the United States useful information on subjects connected with agriculture, in the most general and comprehensive sense of that word... . The Secretary of Agriculture shall procure and preserve all information concerning agriculture which he can obtain by means of books and correspondence... by the collection of statistics, and by other appropriate means within his power..." and, finally that, "The Secretary of Agriculture shall have charge ... of the $\mathrm{Li}$ brary. ..."

This act, which recognized the importance of the knowledge contained in literature, and of library services, is probably unique in federal legislative history, and it defines the national responsibility of the Department of Agriculture Library.

In addition, since we serve as the $\mathrm{Li}$ brary of the Department of Agriculture, we must provide literature which is required for the day-to-day work of the staff in many other fields. An organization like the U.S. Department of Agriculture, with a staff

1 Paper presented at the Conference of Eastern College Librarians, Columbia University, Nov. 29, I947. ranging between sixty thousand and a hundred thousand people, scattered all over the country, has personnel officers who must be equipped with current personnel literature, budget and fiscal officers who must be helped in performing their jobs, and many related service functions which require supporting library services.

Thus, in its departmental relationships the Department of Agriculture Library has the two-fold job of supporting the bibliographical needs of a program of research which averages approximately $\$ 30,000,000$ a year, and an administrative program of about $\$ 1,000,000,000$ a year.

As noted in the current Yearbook of $\mathrm{Ag}$ riculture, we cannot separate agricultural science from other sciences. Agricultural research workers use the principles developed in the fundamental sciences, such as chemistry, geology, or botany, and also contribute to them. The term agricultural science is useful; it means, generally, all scientific principles as they apply to farming and to rural living. But we cannot have an agricultural chemistry apart from chemistry, nor an agricultural economics apart from economics. The fundamental principles of production economics are the same, whether applied to farm organizations or the manufacture of automobiles. In striving for solution to agricultural problems, then, it is often necessary to carry on research in the basic natural and social sciences to develop principles for application.

These factors provide our frame of reference. We are required by our charter: 
First, to collect all the knowledge about agriculture which can be obtained from publications and to make that knowledge available to the country as a whole, and, second, to provide the staff library services needed in the day-to-day operation of the country's greatest civilian research institutution.

Library materials and services falling within the first category are considered our primary research field. Much of the material and service required by the second category of responsibilities does not differ from what we are required to provide to the nation as a whole. Provision of materials and services not included in our national responsibility is considered supplementary service functions only - and in this area we rely upon other libraries for research collections and services.

In view of the scope of agriculture as defined and of the related sciences which are a fundamental part of agricultural research and administration, it is obvious that some limitation had to be self-imposed if the department library was to avoid duplication of all other great research libraries. As a practical matter since the country has never supported even one national library adequately to provide for complete coverage of the world's literature on a current basis, it would appear uneconomical and unwise to attempt unnecessary duplication of research facilities.

This was recognized early. For example, although the department library has legal authority to publish and sell catalog cards, and actually performed that function until 1906, it has been considered more economical to supply copy to the Library of Congress, limiting the stocking of catalog cards and the servicing of such cards to only one agency.

Likewise, there appears little point in competitive bidding for rare books among the three great national libraries, and the Department of Agriculture Library has specifically foresworn that field.

The scope of our work is broad, but it does not defy definition, and the fields in which we attempt to acquire everything, are fairly readily defined. While we do purchase in other fields, such purchases are limited to working collections needed for current work, because we have found that we can rely upon our neighbors for research collections in related subject fields.

From its very beginnings, Agriculture's library has been slanted toward procuring and supplying knowledge rather than toward dealing with books or periodicals primarily as physical objects.

For this reason you will find that our subject treatment of material is based on its intellectual content rather than on its format, and we are likely to make as many or more subject headings for a slight mimeographed separate as we do for a textbook. On the other hand, since we are concerned with the dissemination of knowledge rather than with bibliophilic considerations, you will find that our descriptive cataloging is more informal than that in many other scholarly libraries, in which the detailed description of a particular copy of a book has been considered an absolutely essential part of the cataloging process.

In a library like ours, consulting the literature is just another way of consulting all the experts or alleged experts, of all times and places, who have written down what they know about the subject under consideration. Thus our book stock, instead of being considered in terms of a given number of books, becomes a corps of five or ten million or more experts who stand prepared to provide facts and judgments about all aspects of our work.

Under this concept- "Technical Processes" involve bringing these experts to- 
gether and hooking up a communications system so that the desired specialists may be called up to testify as required. "Reference Services" bring the expert and inquirer together (for feeless consultation). "Bibliographical Services" convert the testimony into more usable form by selection of the evidence that bears on the question, organization of the knowledge, conversion of the knowledge into more usable form, and, in some cases, by interpretation and evaluation of the testimony. And, "Lending Services," including our system of field branches, as well as auxiliary methods such as photographic reproduction, are means for bringing the expert's testimony to his clients at points other than his permanent office in the library stacks.

Our dependence upon the Army Medical Library for medical literature and upon the Library of Congress for general materials has increased our own research potential in two ways. First, it has made available to those whom we serve the total potential of all three of these great collections, and second, it has freed our own resources for more adequate collection, organization, and dissemination of the knowledge in our own basic research fields.

The extent of our use of the Library of Congress collections is indicated by the fact that we have stationed a staff member at that library half or full time to use its collections to supplement our own.

The most important result of our emphasis in cooperative use of resources is the extent to which it has left our own resources free for bibliographical research and service. Our Division of Bibliography, consisting of 35 to 40 staff members, most of whom are professional librarians with strong subject or subject-literature backgrounds, provides a steady flow of specialized subject bibliographies and of new and important tools of research such as the
Index to the Literature of American Economic Entomology, the Plant Science Cata$\log$, and the Bibliography of Agriculture.

Each month the Bibliography of Agriculture provides a classified list of some 5,000 to 7,000 articles or separates. This bibliography is sent to all the offices of the department and is available to all of the staff. By using the author and subject indexes which appear in each month's issue, a member of the staff of the department is able to determine in fifteen or twenty minutes each month substantially all that has been published any place in the world that affects his work. A postcard or call to the library, or to any of its branches, brings to him any item of interest either in the orginal or in photographic reproduction.

The same service is available to everyone, except that those not employed by the department may have to subscribe to the Bibliography of Agriculture. If the literature in which they are interested is not available in their local libraries they may have to pay the cost of photographic copies. In effect, this places the world's agricultural literature on the desk of every man who is willing to exert a minimum amount of effort to get it.

Additional bibliographic services include the preparation of some one hundred special bibliographies annually, ranging from airplane dusting for insect control, to use of milkweed floss as a substitute for kapok, as well as such popular tools as our rural reading list and our list of standard agricultural books. In addition to bibliographical research services, this library provided answers to some 200,000 reference questions and loaned I,750,000 volumes, largely by mail, during the past year.

The Department of Agriculture Library is a great national resource. It is not merely the library of the Department of Agriculture, but it is your library and that of all the people of the United States. 